\title{
A Study on Grid-Square Statistics Based Estimation of Regional Electricity Demand and Regional Potential Capacity of Distributed Generators
}

\author{
Takeyoshi Kato Member (Nagoya University, tkato@nuee.nagoya-u.ac.jp) \\ Hiroyuki Sugimoto Student Member (Nagoya University, hiroyu_s@echo.nuee.nagoya-u.ac.jp) \\ Yasuo SuzuokiＭember（Nagoya University, suzuoki@nuee.nagoya-u.ac.jp)
}

Keywords: distributed generators, PV system, co-generation system, distribution system, potential capacity

We established a procedure for estimating regional electricity demand and regional potential capacity of distributed generators (DGs) by using a statistical mesh data set. A photovoltaic power system (PV system) for residential use and a co-generation system (CGS) for both residential and commercial use (three business categories, i.e. hotel, hospital, store) were taken into account. The statistical data on the number of households by family type and the number of employees by business category for about 4000 meshes with $1 \mathrm{~km} \times 1 \mathrm{~km}$ area was used to estimate the floor space or the electricity demand distribution. The rooftop area available for installing PV systems was also estimated with the statistical mesh data set. Considering the relation between a capacity of existing CGS and a scale of building where CGS is installed, the potential capacity of CGS in the commercial sector was estimated.

As an example, the result regarding Aichi prefecture was presented in this paper. Fig. 1 shows the distribution of maximum electricity demand in each mesh. The maximum electricity demand is smaller than $3.2 \mathrm{MW} / \mathrm{km}^{2}$ in $90 \%$ mesh, suggesting that the area with large electricity demand is very limited.

Figure 2 shows the potential capacity of PV system as an example. In some meshes, the potential capacity of PV systems was estimated to be about $10,000 \mathrm{~kW} / \mathrm{km}^{2}$, which corresponds to the density

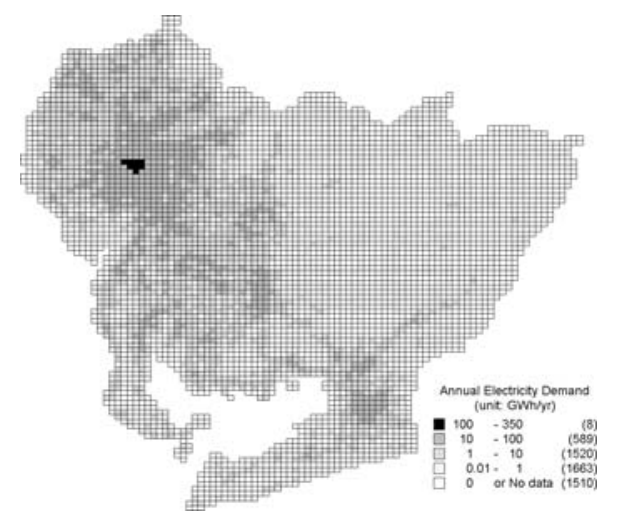

Fig. 1. Distribution of regional annual electricity demand of the existing area with intensive installation of PV systems. The estimated potential capacity of CGS was much smaller than that of PV system because of limited number of CGS's users.

Figure 3 shows the ratio of regional potential capacity of DGs to regional maximum electricity demand. The result can be useful for deducing the appropriate capacity of DGs in the model of future electricity distribution system.

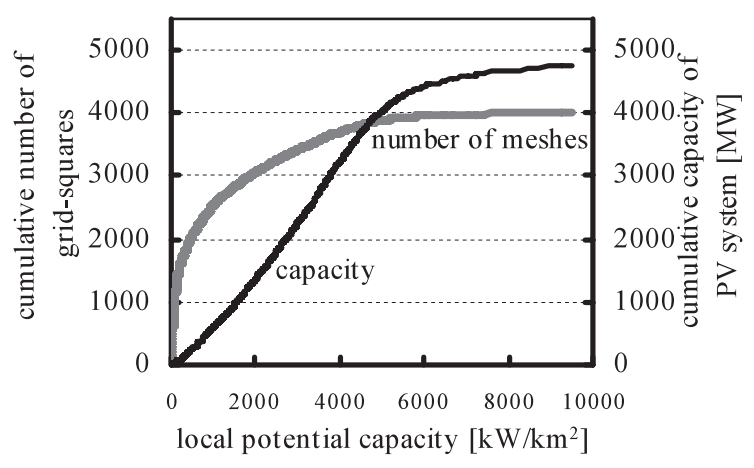

Fig. 2. Potential capacity of residential PV system in grid-square

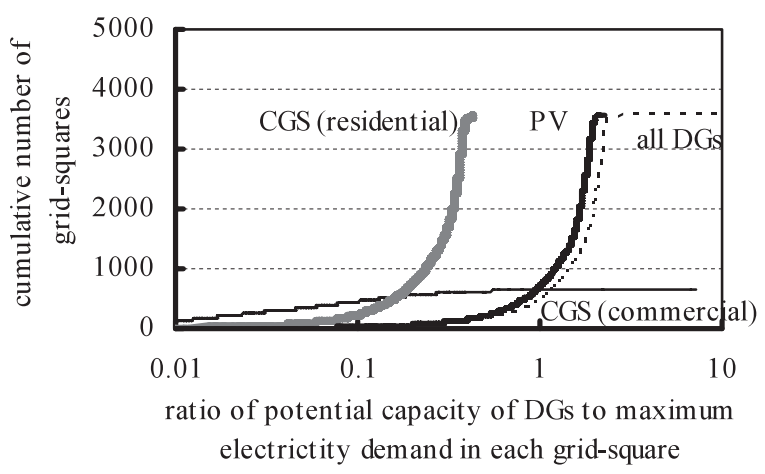

Fig. 3. Ratio of potential capacity of distributed generators to maximum electricity demand in grid-square 


\title{
地域メッシュ統計を用いた地域の電力需要および 分散型電源賦存量の算定に関する一検討
}

\author{
正 員 加藤 丈佳* 学生員 杉本 寛幸* \\ 正 員 鈴置 保雄*
}

\section{A Study on Grid-Square Statistics Based Estimation of Regional Electricity Demand and Regional Potential Capacity of Distributed Generators}

Takeyoshi Kato*, Member, Hiroyuki Sugimoto*, Student Member, Yasuo Suzuoki*, Member

\begin{abstract}
We established a procedure for estimating regional electricity demand and regional potential capacity of distributed generators (DGs) by using a grid square statistics data set. A photovoltaic power system (PV system) for residential use and a co-generation system (CGS) for both residential and commercial use were taken into account. As an example, the result regarding Aichi prefecture was presented in this paper. The statistical data of the number of households by family-type and the number of employees by business category for about 4000 grid-square with $1 \mathrm{~km} \times 1 \mathrm{~km}$ area was used to estimate the floor space or the electricity demand distribution. The rooftop area available for installing PV systems was also estimated with the grid-square statistics data set. Considering the relation between a capacity of existing CGS and a scale-index of building where CGS is installed, the potential capacity of CGS was estimated for three business categories, i.e. hotel, hospital, store. In some regions, the potential capacity of PV systems was estimated to be about $10,000 \mathrm{~kW} / \mathrm{km}^{2}$, which corresponds to the density of the existing area with intensive installation of PV systems. Finally, we discussed the ratio of regional potential capacity of DGs to regional maximum electricity demand for deducing the appropriate capacity of DGs in the model of future electricity distribution system.
\end{abstract}

キーワード : 分散型電源, 太陽光発電システム, コージェネレーションシステム, 配電系統, 賦存量

Keywords: distributed generators, PV system, co-generation system, power distribution system, potential capacity

\section{1. まえがき}

エネルギーの効率的利用や $\mathrm{CO}_{2}$ 排出削減に向けて，太 陽光発電 (PV) システムやコージェネレーションシステム (CGS) などの分散型電源の導入拡大が期待されている。導 入拡大のためには, 分散型電源の種類や地域の導入規模等 の状況に応じて適切な対応を行い，導入制約を小さくする ことが重要である。導入状況は地域の需要家構成によって 異なるため, 分散型電源の導入拡大への対応を中長期的な 視点から計画的に行うためには, 様々な地域について, 各種 分散型電源の賦存量や電力需要との関係を把握する必要が ある。また，地域の再開発に伴うエネルギー供給の高効率 化や都市災害時の非常用電源など，分散型電源の新しい価 值を評価するためにも，様々な地域における分散型電源の 賦存量を統計的に算定できることが望ましい。しかし，分

\footnotetext{
名古屋大学大学院工学研究科

于 464-8603 名古屋市千種区不老町

Graduate school of Engineering, Nagoya University

Furo-cho, Chikusa-ku, Nagoya 464-8603
}

散型電源の賦存量については, 全国や特定地域に関する試 算例は報告されているものの ${ }^{(1)}$, 様々な地域を対象とした 賦存量の統計的な評価や, 地域の電力需要との相関につい ては十分に検討されていない。

そこで本論文では, 配電区域程度の大きさの様々な地域 における民生部門の電力需要および分散型電源の賦存量を 算定することを目的として, 基礎データとして地域メッシュ 統計 (2)(3) の利用に着目し, 地域単位で電力需要と分散型電 源の賦存量を算定する手法を提案する。また, 提案手法に よる算定結果の妥当性や誤差の程度を示すため, 分散型電 源として住宅部門の PV システムと CGS, 業務部門の CGS を対象として，愛知県の約 4000 メッシュ（約 $1 \mathrm{~km}^{2} /$ メッ シュ）について, 電力需要と分散型電源賦存量とを試算し た。最後に, 両者の相関を示し, 様々な地域を対象とした 分散型電源大量導入の影響に関する統計的評価への展開の 可能性について考察した。

\section{2. 地域メッシュ統計}

地域メッシュ統計とは，国勢調査および事業所・企業統 
表 1 業務部門の業種分類と従業員あたりの延床面積の想定

Table 1. Demand-type classification in commercial sector and assumption of floor space per employee.

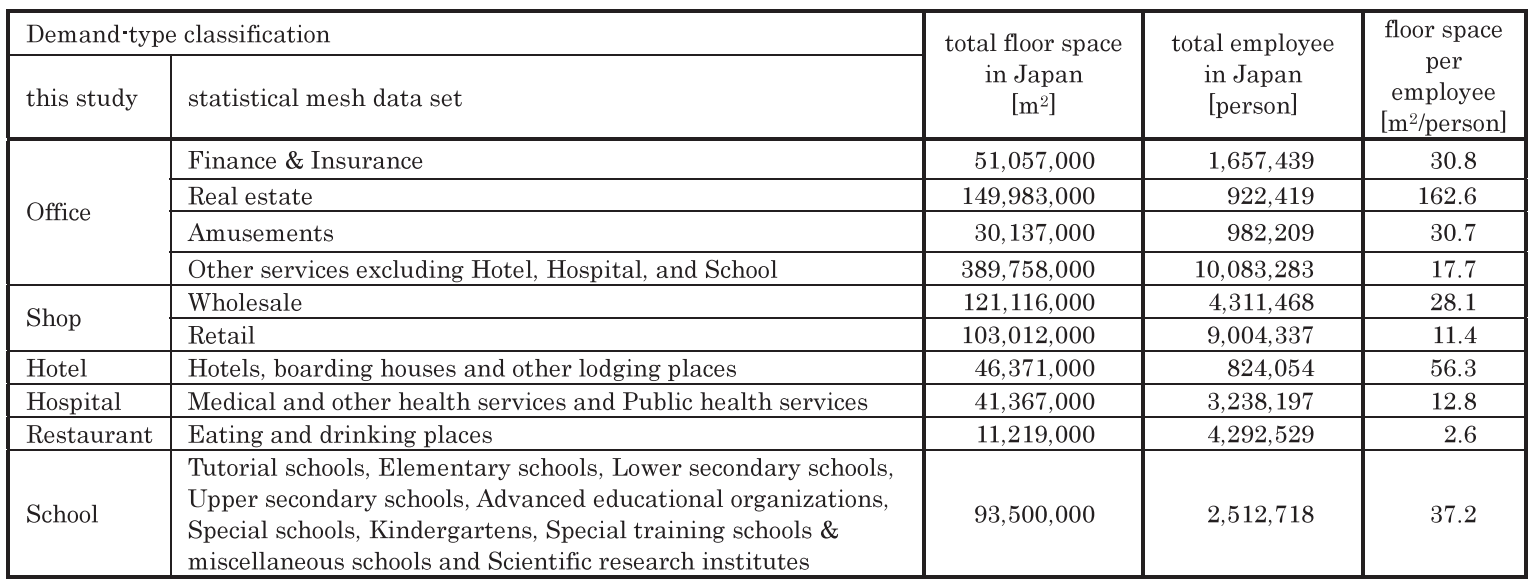

計調査の結果について，全国を緯度・経度により区分した 面積約 $1 \mathrm{~km}^{2}$ と約 $0.25 \mathrm{~km}^{2}$ の方形の小地域区画（それぞれ 3 次メッシュおよび 4 次メッシュと呼ばれる) に再編成し たデータベースである(2)(3)。本論文では，愛知県を検討例 として, 下記の民生需要に関するデー夕項目が存在する約 4000 個の 3 次メッシュについて, 電力需要拐よび分散型電 源の賦存量を算定した。

地域メッシュ統計における各種データ項目のうち，各需 要家の地域分布に関するデータとして, 本論文では以下の データ項目を用いた。

住宅部門

- 建て方別の世帯数（一戸建，長屋建，共同）

-世帯人員別の世帯数（1 人 6 人および 7 人以上）

- 共同住宅の 1 2 階に住む世帯数

・一世帯あたりの住宅延床面積

業務部門

- 業種別の従業員数

また，地域メッシュ統計以外にも，全国の業種別従業員数・ 延床面積, CGS の導入実績等の統計デー夕を用いて, 電力 需要や分散型電源の導入量に関する原単位作成した。次節 以降扮いて，それぞれのデー夕の具体的な利用方法を示す。

\section{3. 各メッシュにおける電力需要}

$\langle\mathbf{3} \cdot 1\rangle$ 需要家の検討対象 地域の電力需要の算定に 関しては, 以下に示寸 9 種類の民生需要家を対象とした。

住宅部門：一戸建住宅，長屋建住宅，共同住宅

業務部門: 事務所, 店舗, ホテル, 病院, 飲食店, 学校 住宅部門については，住宅の建て方別に 3 種類を想定した。 業務部門については, 実際には様々な種類の需要家が存在 するが, 電力需要の算定のため, 電力・熱需要の原単位が 既知の 6 種類の業種に分類し，業務部門全体の需要家を表 すこととした。表 1 に本論文に打ける 6 種類の業種分類と 地域メッシュ統計に扔ける業種分類との対応を示す。

$\langle\mathbf{3} \cdot \mathbf{2}\rangle$ 延床面積の算定後述のように，各メッシュ
の電力需要の算定では, 住宅部門㧍よび業務部門ともに, 単位延床面積あたりの需要原単位を用いる。しかし, 地域 メッシュ統計では，住宅部門の建て方別や業務部門の業種 別の延床面積に関するデータ項目がない。一戸建, 長屋建 および共同住宅の平均延床面積に関するデー夕項目はある が，後述するように PV システムの設置可能面積の算定で は, 建て方別に延床面積に基づき算定した建築面積に関す るデータが必要である。

そこで本論文では, 図 1 および以下に示す手順により, 住宅部門 (住宅の建て方別), 業務部門（業種別）に各メッ シュ内の総延床面積を算定した。同図において, 台形で示 される項目は地域メッシュ統計などの統計データを表し, 四角形で示される項目は統計デー夕等に基づき算定した原 単位などを表す。なお, 本論文では, 各メッシュ内の需要 家の分布を考慮しないため, 需要家の種類別に各メッシュ の合計の延床面積を算定できればよく, 個々の需要家の延 床面積を算定する必要はない。

各メッシュにおける住宅部門の総延床面積（建て方別） の算定では，まず，住宅・土地統計調査に基づき，建て方 別の一世带あたりの延床面積を一戸建住宅：132 $\mathrm{m}^{2}$, 長屋 建住宅 : $53 \mathrm{~m}^{2}$, 共同住宅 : $48 \mathrm{~m}^{2}$ と想定した。これらの值 は愛知県の平均值 (4) であり, 全てのメッシュにおいて同じ とした。それぞれの值に各メッシュに扔ける一戸建，長屋 建, 共同の各住宅の世帯数を乗じて, 各メッシュの総延床 面積を算定した。

この方法で計算した愛知県の住宅全体の総延床面積は約 $228 \mathrm{~km}^{2}$ であった。比較として, 地域メッシュ統計の平均延 床面積 (一戸建, 長屋建㧍よび共同住宅の各メッシュに扩け る平均值）から求めた愛知県内の総延床面積は約 $227 \mathrm{~km}^{2}$ となり，上述の方法で計算した結果とほほ一致した。メッ シュごとに比較すると多少のばらつきはあるものの, 76\%の メッシュにおいて, 総延床面積の違いが $\pm 30 \%$ 以内であり, 上述のような建て方別の一世帯あたりの平均延床面積を用 いた各メッシュにおける住宅部門の総延床面積の計算は概 


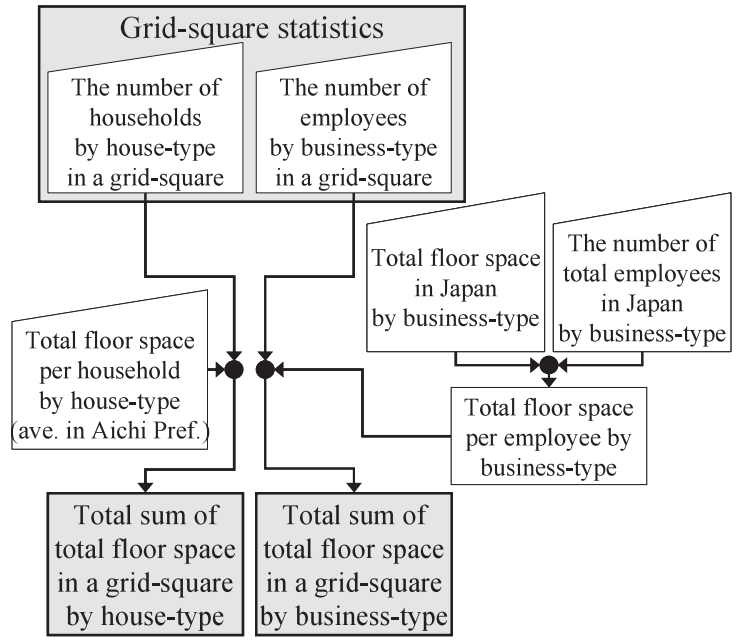

図 1 各メッシュにおける需要家延床面積の算定手順

Fig. 1. Steps to calculate total floor space of each demand type in each grid-square.

ね妥当な見積もりが可能であると見なした。

各メッシュに㧍ける業務部門の延床面積（業種別）の算 定では，まず，表 1 に示す業種別の全国合計の延床面積 (5) と従業者数 (6)に基づき，同表右端に示すように従業員 1 人 あたりの延床面積を算定した。その值に各メッシュの該当 業種の従業者数を乗じて，各メッシュに扔ける業種別の延 床面積を算定した。なお，このような算定方法では，利用 可能な統計デー夕が限られるため, 結果には相応の誤差が 含まれると考えられる。そこで，今後，各メッシュにおけ る業務部門の延床面積をより適切に算定するためには，代 表的な地域について延床面積の実態調査結果等に基づき, 表 1 に示した従業員あたりの延床面積について，地域性を 考慮した補正が必要と考えられる。

$\langle\mathbf{3} \cdot \mathbf{3}\rangle$ 電力需要の算定 各メッシュについて算定し た需要家別の総延床面積に，需要家別の 12 ケ月 $\times 24$ 時間 の電力需要原単位 (7) を乗じて各時間带の電力需要を算定し た。照明動力などの電力固有の需要だけでなく, 用途別需 要のエネルギー源内訳に基づき ${ }^{(8)}$, 暖房, 冷房, 給湯, 厨房 についても電力需要として計上した。その際，冷房用の電 力需要については住宅部門抄よび業務部門ともに空調機器 の COP を 3 と想定した。また, 暖房用の電力需要の算定 においては，業務部門のみ空調機器の COP 4 と想定し た。住宅部門の暖房用電力需要については, エアコンだけ なく電熱式ヒータなども含まれるため, COP を 3 とした。 な挹, 需要家別の電力需要原単位が平均的な值であること から，等価的に同じ需要家における同時使用率が考慮され ていると考えることができる。

このような方法により, 各メッシュについて, 需要家別に 月別・時刻別の電力需要を算定し，それらを集計してメッ シュ全体の電力需要パターンを算定した。図 2 に愛知県に おける民生部門の年間電力需要の分布を示す。また，図 3 に各メッシュの年間電力需要を示す。同図の横軸は各メッ

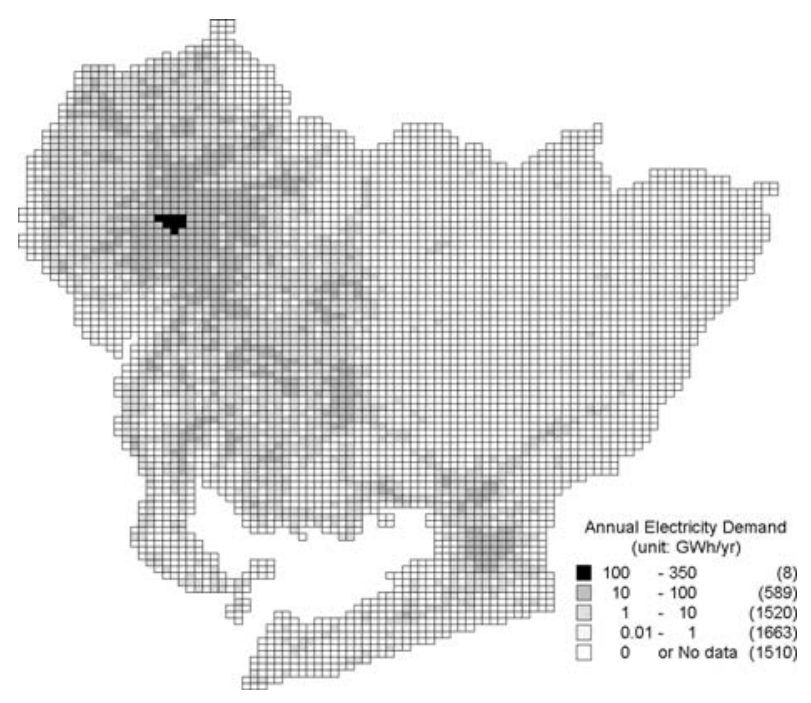

図 2 年間電力需要の地域分布

Fig. 2. Distribution of regional annual electricity demand.

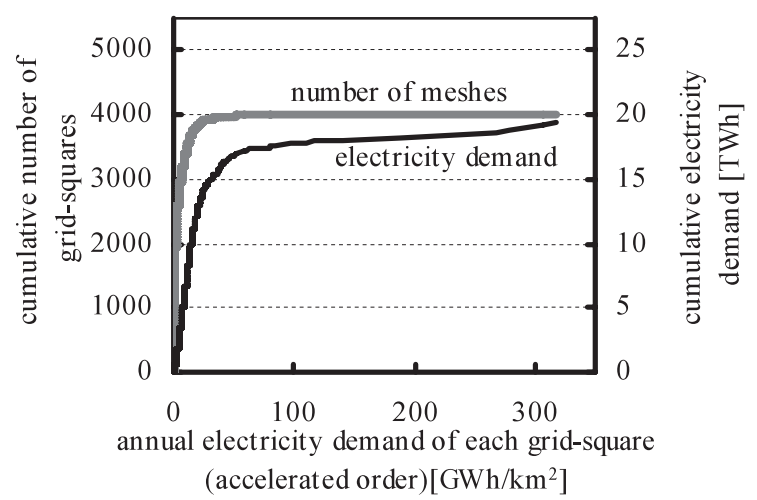

図 3 各メッシュにおける年間電力需要

Fig. 3. Annual electricity demand in grid-square.

シュの年間電力需要の昇順, 左側緹軸はメッシュ数の累積 值, 右側縦軸は全メッシュの年間電力需要の累積值を示す。 図 2 拉よび図 3 に示すように, 年間電力需要が大きなメッ シュ数は限られており，90\%のメッシュに拈いて年間電力 需要は約 $13 \mathrm{GWh} / \mathrm{km}^{2}$ 以下であった。また, 図 3 からわ かるように, 愛知県の約 4000 個の 3 次メッシュの合計の 年間電力需要は約 $19.4 \mathrm{TWh}$ となった。比較として, 平成 12 年度に扔ける愛知県内の電灯用契約扔よび業務用電力契 約の販売電力量の実績值はそれぞれ約 $14.2 \mathrm{TWh}$ および約 $8.6 \mathrm{TWh}$ であった。業務用電力契約している需要家の中に は, 規模が大きい業務部門の需要家が含まれることを考慮 すると, 地域メッシュ統計に基づく電力需要の算定は, 総量 については概ね妥当な值を得ることができると考えられる。

図 4 に各メッシュの年間の最大電力需要 (横軸, 昇順) と累 積メッシュ数と関係を示す。年間電力需要の場合と同様に最 大電力需要が大きなメッシュ数は限られており, $90 \%$ のッ シュに拈いて最大電力需要は約 $3.2 \mathrm{MW} / \mathrm{km}^{2}$ 以下であった。

上述の電力需要の算定方法においては, 適切な延床面積 の算定と電力需要原単位の想定が重要である。延床面積の 


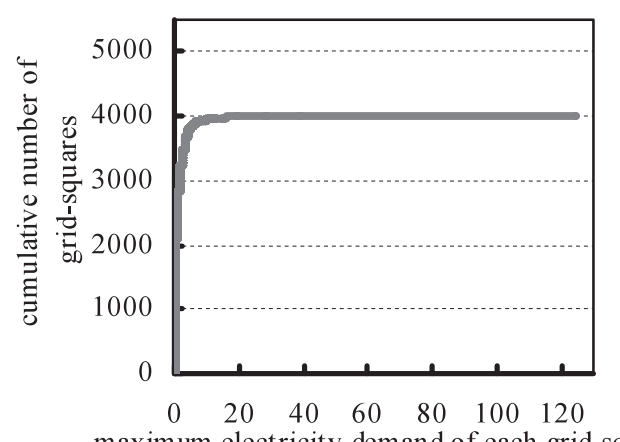

maximum electricity demand of each grid-square (accelerated order) $\left[\mathrm{MW} / \mathrm{km}^{2}\right]$

図 4 各メッシュにおける最大電力需要

Fig. 4. Maximum electricity demand in each grid-square.

算定に関しては, 実態調査結果に基づく補正等により, 誤 差を小さくできる。また, 電力需要原単位についても, 全 国各地の様々な地域を対象とした検討を行うためには，地 域の気象条件を考慮して電力需要原単位を設定する必要が ある。その際，家庭部門については，個人の行動パターン や使用する電気機器の違いを考慮した世带類型別の電力需 要の算定 ${ }^{(9)}$ を適用することで, より適切な算定が可能にな ると考えられる。これらについては，今後の課題とする。

\section{4. 各メッシュにおける分散型電源の賦存量}

$\langle\mathbf{4} \cdot \mathbf{1}\rangle$ 分散型電源の検討対象 配電系統に導入され る分散型電源として, 住宅用の PV システムと CGS および 業務用のCGS を対象とした。これらの分散型電源は，気 象条件等による地域的な導入制約が小さく, 需要家の分布 と賦存量との相関が高いため, 統計的に賦存量を算定でき ることは有意義である。これら以外にも，小型の風力発電 等の分散型電源が考えられるが, 賦存量は風況などの地域 に固有の条件によって異なり，統計的に扱うことが困難で あるため，本論文では対象としていない。

$\langle 4 \cdot 2\rangle$ 住宅用 PV システム賦存量 四 5 に住宅用 PV システム賦存量の算定手順を示す。図 1 と同様に, 各デー 夕項目は, 出所や想定方法に応じて台形掞よび四角形で示 されている。さらに, 六角形で示されている項目は, 過去 の事例や典型例などに基づき想定した項目を表す。

まず，各メッシュに扔ける住宅の建て方別の総建築面積 を算定した。一戸建住宅については, 住宅·土地統計調査 ${ }^{(10)}$ に抢ける「一住宅あたりの建築面積」の愛知県の平均値に 基づき，一世带あたりの建築面積を $88 \mathrm{~m}^{2}$ とし，この值に 各メッシュ内の一戸建住宅に住む世帯数を乗じて, 各メッ シュの一戸建住宅の総建築面積を算定した。長屋・共同住 宅については，一世带につき 1 階層しか占有しないと仮定 し, 建物の建築面積はその建物の 1 階に住む世帯の延床面 積とした。すなわち，長屋住宅については，全て 1 階建て と想定し, 延床面積 : $53 \mathrm{~m}^{2}$ にメッシュ内の長屋住宅に住 む世帯数を乗じて, 各メッシュの長屋建て住宅の総建築面 積を計算した。共同住宅については，2 階建以上の共同住

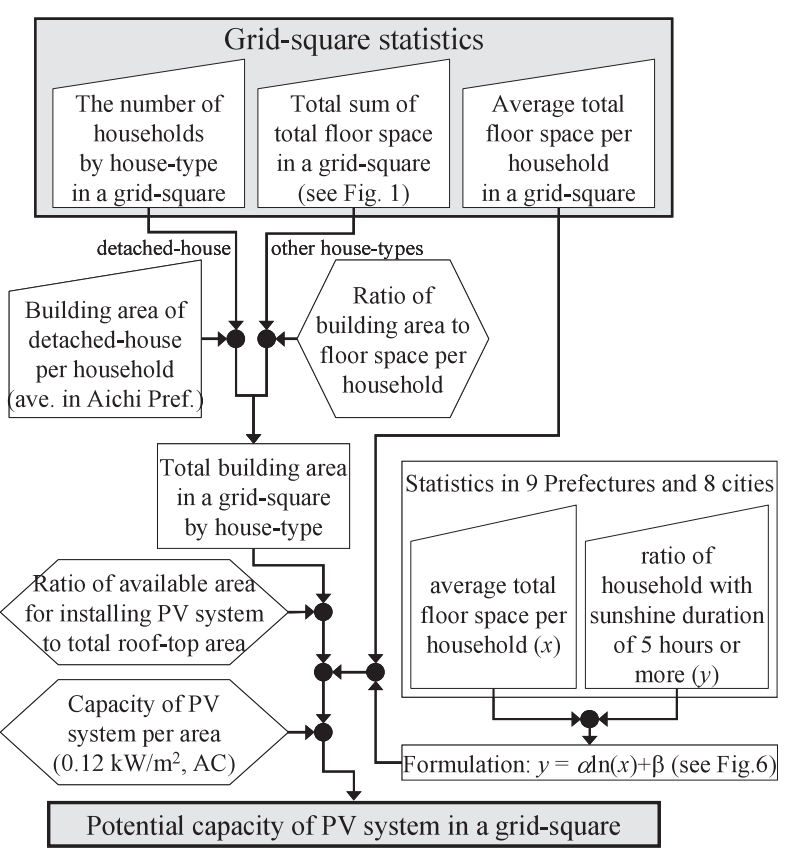

図 5 各メッシュにおける PV システム賦存量の 算定手順

Fig. 5. Steps to calculate potential capacity of PV system in each grid-square.

宅が多いことを考慮して，延床面積： $48 \mathrm{~m}^{2} に 「 1 \cdot 2$ 階に 住む共同住宅世帯数」の半数（端数切り上げ）を乗じて, 各 メッシュの共同住宅の総建築面積を算定した。

次に, 以下に示すように PV システムを設置可能な屋根面 積の割合を想定し, 各メッシュにおける PV システムの設置 可能な屋根の総面積を算定した。PV システムの集中導入地 区である群馬県太田市城西の杜では, 屋根形状やモジュー ルの形状・寸法が異なる一戸建住宅（約 320 軒, 2005 年 7

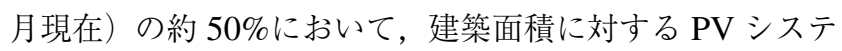
ムの設置面積の割合は 30\% 40\%であり, 約 15\%の住宅で は建築面積に対する PV システムの設置面積割合は $50 \%$ 以 上である(11)。しかも，城西の杜における全ての PV システ ムは架台や金具を使用して設置する「屋根置き型」であり， 今後, 無䭾なスペース無く設置可能な「建材一体型」が普及 すれば，屋根面積に対する PV システムの設置可能面積が 増加する可能性もある。そこで本論文では，一戸建住宅に おける PV システムの設置可能な屋根面積の割合を $40 \%$ と 想定した。一方, 長屋建㧍よび共同住宅については, PV シ ステムを設置し易い切妻屋根や陸屋根の割合が大きいこと を考慮して, 建築面積に対する PV システムの設置可能な 屋根面積の割合を $50 \%$ と想定した ${ }^{(12)}$ 。

さらに，PV システムは日当たりの良い住宅に設置され ると想定した。住宅に扔ける日当たり条件の良さを表す尺 度に関して利用可能な統計データとして, 平均日照時間が 5 時間以上の世帯の割合 ${ }^{(13)}$ を用いることとした。なお，こ の日照時間は, 10 月 1 日前後の晴天の日に居住室に日が当 たっている時間を世带の回答によって調査した結果である。 


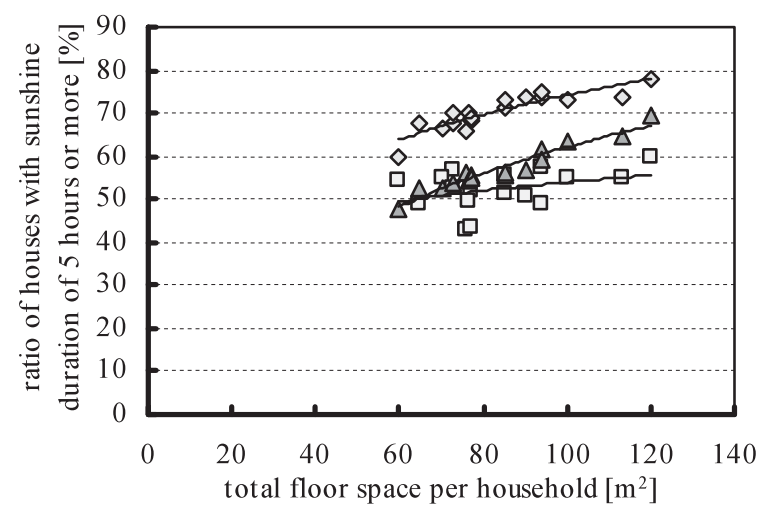

図 69 県・8 都市における 1 世帯あたりの延床面積と 日照時間 5 時間以上の住宅の割合との関係

Fig. 6. Relation between total floor space per household and ratio of houses with sunshine duration of 5 hours or more in 9 Prefectures and 8 cities.

本論文では，各メッシュについて日照時間 5 時間以上の世 帯の割合を算出し，上述の各メッシュにおける PV システ ムが設置可能な屋根の総面積に乗じて, PV システムの設 置面積を算出した。ただし，世帯における平均日照時間に 関する統計デー夕は，県，大都市圏および政令指定都市の 単位で公表されているにすぎない。そこで，各メッシュに おける日照時間 5 時間以上の世帯の割合を以下のように想 定した。

まず，本論文で対象としているような同一県内の様々な 地域における日照時間の差は，気象条件の差ではなく，地 域における建物の密度や形状などの差の影響が大きいと考 える。一般に, 建物密度が高い地域では, 高層の集合住宅 の割合も大きく，1 世帯あたりの延床面積も小さくなると 考えられる。一方，地域メッシュ統計には，各メッシュに おける 1 世帯あたりの平均延床面積のデー夕項目がある ${ }^{(2)}$ 。 そこで, 愛知県および県内の各都市と住宅条件や日照条件 が類似すると考えられる9県 (千葉県, 神奈川県, 静岡県, 愛知県，岐阜県，三重県，兵庫県，広島県，福岡県）と 8 都市（千葉市，川崎市，横浜市，名古屋市，神戸市，広島 市，北九州市，福岡市）について，1 世帯あたり住宅延床面 積 $x$ と平均日照時間 5 時間以上の世帯の割合 $y$ との相関図 を図 6 に示すように作成し，次式のように定式化して，各 メッシュにおける平均日照時間 5 時間以上の世帯の割合を 算出した。

$$
\text { 一戸建住宅： } y=20.4 \times \ln (x)-19.7 \quad\left(R^{2}=0.80\right)(\%)
$$

長屋建住宅： $y=49.2(\%)$

共同住宅： $\quad y=27.3 \times \ln (x)-63.4 \quad\left(R^{2}=0.92\right)(\%)$

ただし，図6のロ印にて示すように，長屋建住宅につい ては，各県・都市の実績值から算出した 1 世帯あたり住宅 延床面積と平均日照時間 5 時間以上の世帯の割合との間に 明確な相関が見られなかったため，全てのメッシュについ て, 平均日照時間 5 時間以上の世帯の割合として愛知県の

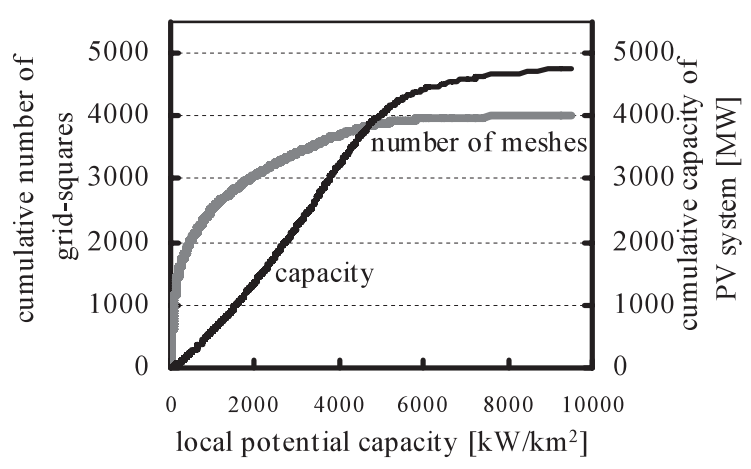

図 7 各メッシュにおける住宅用 PV システムの 賦存量

Fig. 7. Potential capacity of residential PV system in each grid-square.

值を用いた。最後に, 単位設置面積あたりの PV システム の設備容量 (交流出力) $0.12 \mathrm{~kW} / \mathrm{m}^{2}$ と想定して設置可 能面積に乗じ, 各メッシュにおける住宅用 PV システムの 賦存量を算定した。

図 7 に各メッシュにおける PV システムの賦存量を示す。 同図の横軸は各メッシュの賦存量の昇順, 左側縦軸は累積 メッシュ数, 右側縦軸は全メッシュの賦存量の累積值を示 す。同図に示すように, 全メッシュ合計の住宅用 PV システ 厶の賦存量は約 4,800 MW であり, 2010 年におけるわが国 の導入目標に匹敵する。個々のメッシュに着目すると，一 戸建住宅が主体の数メッシュにおいて PV システムの賦存 量は $10,000 \mathrm{~kW} / \mathrm{km}^{2}$ 程度となった。比較として, PV シス テムの集中導入地区である群馬県太田市城西の杜では, 平成 17 年 3 月現在, 約 $0.12 \mathrm{~km}^{2}$ のエリア内に約 $1,200 \mathrm{~kW}$ の PV システムが導入されており, 導入密度は約 $10,000 \mathrm{~kW} / \mathrm{km}^{2}$ になる。したがって，本論文で検討対象とした 4000 メッ シュのうち, 数メッシュは PV システムの集中導入の実証 地区と同程度の賦存量となると考えられる。ただ, 大半 のメッシュでは賦存量は数 $1,000 \mathrm{~kW} / \mathrm{km}^{2}$ であり, 導入密 度は最大でも PV システムの集中導入の実証地区の数分の 一程度である。

$\langle 4 \cdot 3\rangle$ 住宅用 CGS 賦存量図 8 に住宅用 CGS 賦存 量の算定手順を示す。市販されているガスエンジン型の発 電機容量は $1.0 \mathrm{~kW}$, 開発中の燃料電池型も $0.7 \mathrm{~kW} \sim 1.0 \mathrm{~kW}$ であることを考慮して，住宅用 CGS の単機容量を $1.0 \mathrm{~kW}$ と想定した。燃料電池型の場合, 発電効率: $35 \%$, 熱回収効 率: $40 \%$ (いずれも LHV) と想定すると, 熱出力は約 $1.1 \mathrm{~kW}$ となり，24 時間連続運転すれば約 $100 \mathrm{MJ} /$ day の排熱回収 が可能である。

住宅用 CGS の設置には，本体と貯湯槽のスペースを確保 する必要があることから, 本論文では, 一戸建住宅のみを 対象とした。なお, 将来的には数 $\mathrm{kW}$ クラスの住宅用 CGS を集合住宅に導入することも考えられるが，適性容量の設 定が困難なため, 本論文では考慮していない。また，一戸 建住宅に関しても, 住宅用 CGS の温水が有効利用されるこ 


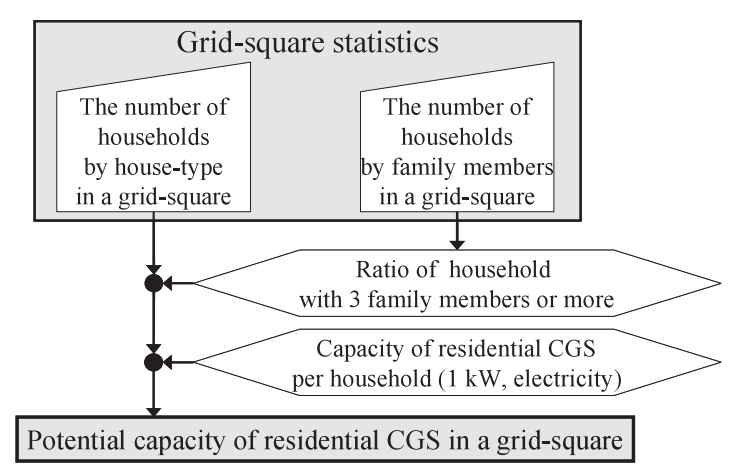

図 8 各メッシュにおける住宅用 CGS 容量の 算定手順

Fig. 8. Steps to calculate potential capacity of residential CGS in each grid-square.

とを前提として, 以下の理由により，世带人員が 3 人以上の 一戸建住宅に導入されるものと想定した。まず，日本建築 学会が実施したアンケート調査の結果 ${ }^{(14)}$ に基づき，世带人 員別・月別に一日あたりの温水需要を算定した。その結果， 世帯人員 3 人以上であれば，夏期においても $30 \mathrm{MJ} / \mathrm{day}$ 程 度の温水需要となった。この場合, 上述の排熱回収量との 比較により, 住宅用 CGS を負荷率 30\%程度で運転するこ とで，廃棄される熱を小さくできると考えられる。以上の 理由により，本論文では，世带人員が 3 人以上の一戸建住 宅に導入されるものと想定した。なお，上述のアンケート 調査の結果から, 温水需要の地域差は小さいことが確認さ れている。したがって, 本論文に扔ける一戸建住宅用 CGS の発電機容量の想定は，他の地域を対象とした検討におい ても適用できると考えられる。

次に, 各メッシュについて, 世帯人員 3 人以上の一戸建 て住宅数に関するデータが必要になるが，地域メッシュ統 計には，世带人員別の一戸建住宅数に関するデー夕項目は ない。そこで，一戸建住宅のみが存在するメッシュについ て世带人員別の世帯数を算定した結果，世帯人員が 3 人以 上の世帯は約 70\%であった。この值に基づき, 全てのメッ シュについて，一建住宅の $70 \%$ が带人員 3 人以上と想定 した。また, 住宅用 CGS の単機容量は, 電力と熱需要が 無䭾なく利用できるとされる規模として, 電気出力で $1 \mathrm{~kW}$ と想定した。このような想定に基づき, 各メッシュについ て, 一戸建住宅数の $70 \% に 1 \mathrm{~kW}$ を乗じて, 住宅用 CGS の 賦存量を算定した。

図 9 に各メッシュにおける住宅用 CGS の賦存量を示す。 全メッシュ合計の賦存量は約 $1,000 \mathrm{MW}$ であり, PV シス テムよりも小さい。また, メッシュ別の賦存量についても, 最大で $1,800 \mathrm{~kW} / \mathrm{m}^{2}$ 程度であり, $98 \%$ のッシュにおいて $1,000 \mathrm{~kW} / \mathrm{m}^{2}$ 以下，すなわち $\mathrm{PV}$ システムの集中導入の実 証地区の導入密度の 10 分の 1 以下であった。これは, PV システムと比較して, 住宅用 CGS の単機容量は小さく, 一 戸建住宅の 70\%のみに導入されると想定したためである。

なお，本論文に扔ける住宅用 CGS 賦存量の算定方法は，

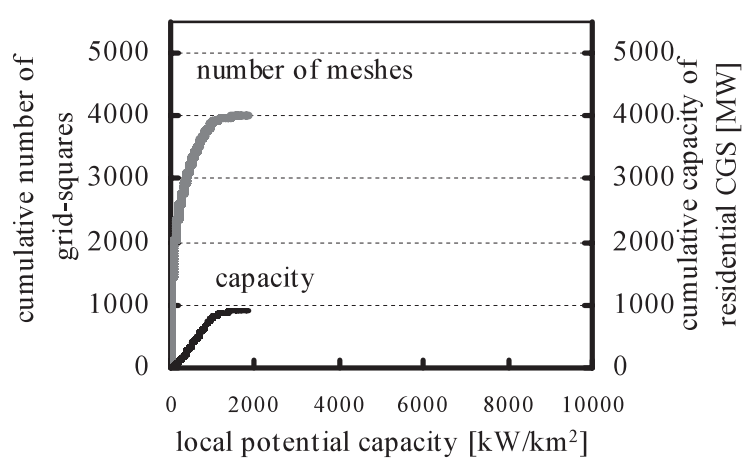

困 9 各メッシュにおける住宅用 CGS の賦存量

Fig. 9. Potential capacity of residential CGS in each grid-square.

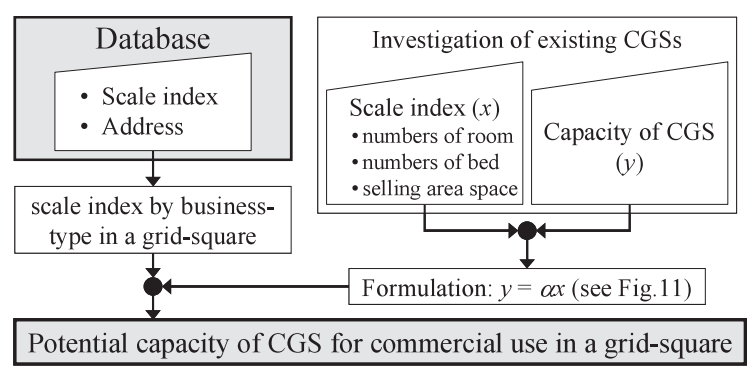

図 10 各メッシュにおける業務用 CGS 容量の 算定手順

Fig. 10. Steps to calculate potential capacity of CGS in commercial sector in each mesh.

基礎データとして地域メッシュ統計に記載の世帯数に基づ いており, 温水供給の観点からも単機容量: $1 \mathrm{~kW}$ は概秝 妥当な大きさと考元られることから, PV システムの場合 よりも誤差は小さいと考えられる。ただし，一軒の住宅に PV システムと CGS とが重複して導入される場合を含んで おり, 実際の導入では PV システムと CGS のうち一方し か導入されない可能性がある。また, 高効率の温水供給機 器という観点では, ヒートポンプ式給湯器との競合も考え られる。そこで, より適切な各分散型電源の賦存量算定に は, Consumer Behavior (CB) 分析に基づいたモデル ${ }^{(15)}$ 等 を応用し，競合を考慮した検討が必要である。

$\langle\mathbf{4} \cdot \mathbf{4}\rangle$ 業務用 CGS 賦存量図 10 に業務用 CGS 賦 存量の算定手順を示す。業務用 CGS の導入対象として, 本 論文では, 温熱需要が大きいホテル, 病院および店舗の 3 業 種のみを対象とし, 温熱需要が小さい事務所や学校などは 対象外とした。まず, 3 業種について, 全国におけるCGS 導入済みの施設の規模と CGS 導入容量とを文献等によっ て調査した(7)(16)。結果を図 11 に示す。施設規模を表す指標 としては, CGS が導入されていない大部分の施設について データの入手が容易な項目として, ホテル: 客室数, 病院： 病床数, 店舗: 売場面積を用いた。これらの実績に基づき, 同図中に示すように，設備規模と設備容量との関倸を定式 化した。

次に, 愛知県内で CGS 未導入の全ての施設について売 


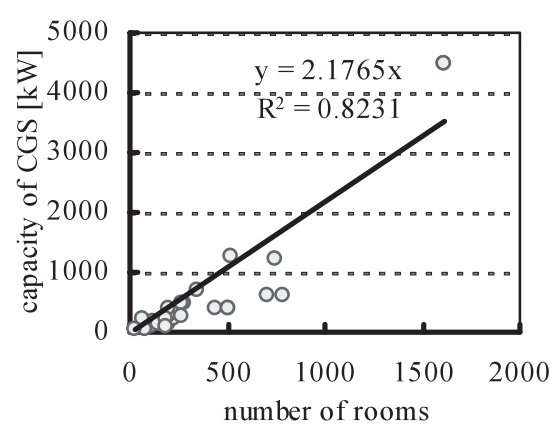

(a) Hotel

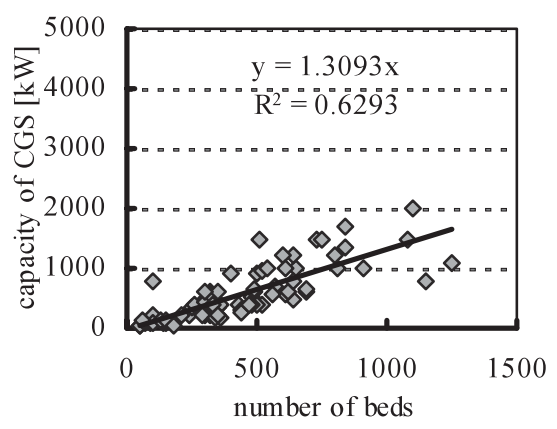

(b) Hospital

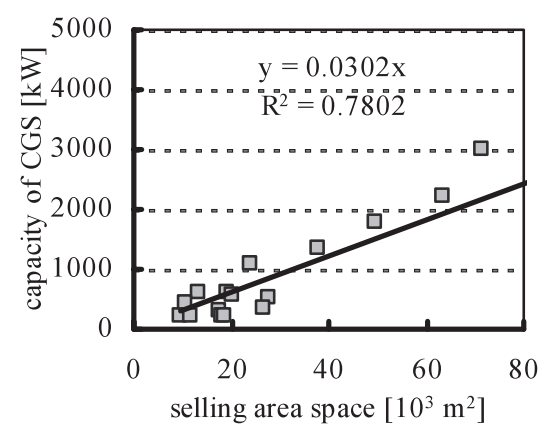

(c) Store

図 11 業務部門 3 業種における建物規模と CGS 導入実績との関係

Fig. 11. Relation between building capacity and installed CGS capacity in three demand types in commercial sector.

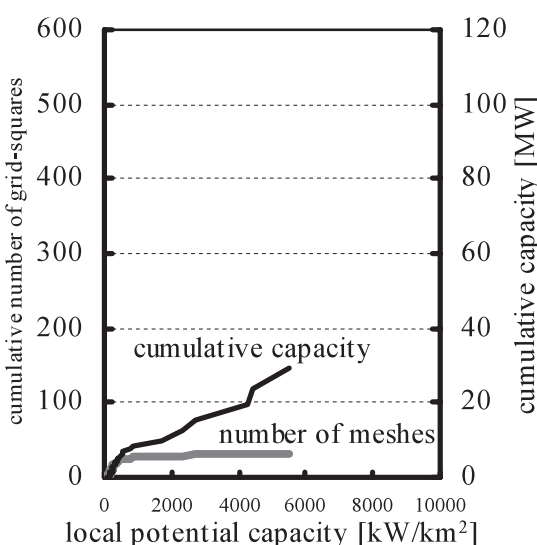

(a) Hotel

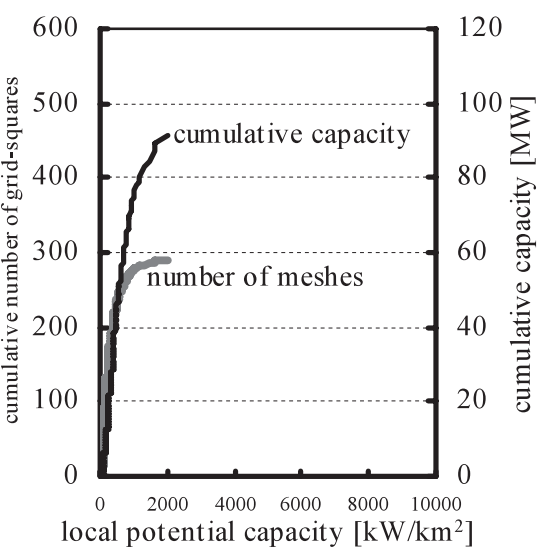

(b) Hospital

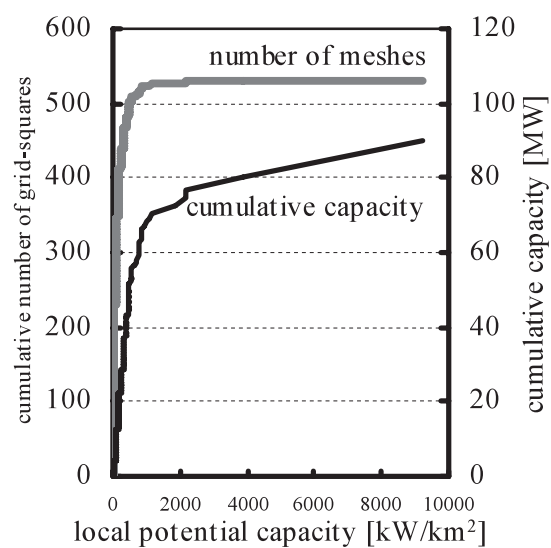

(c) Store

図 12 業務部門 3 業種における CGS 賦存量

Fig. 12. Potential capacity of CGS in three demand types in commercial sector.

場面積などの施設規模を調査し ${ }^{(17) \sim(21)}$ ，上述の相関式を用い て施設ごとに導入可能量を算出した。最後に，各施設の住 所から，対応するメッシュごとにCGS 導入可能量を集計 し，各メッシュにおける業務用 CGS の賦存量を算定した。 なお，このような算定方法においては，図 11 に示した既存 の CGS 導入需要家における施設規模と CGS 容量との関係 式の適切な想定が重要である。現時点では図 11 に示した 程度のばらつきを踏まえて関係式を設定しており，相応の 誤差が含まれる点に留意されたい。

各メッシュにおける業務用 CGS の賦存量の算定結果を 図 12 に示す。同図 (a)のホテルについては，ホテルを含む メッシュ数が限られるため, 全メッシュ合計の賦存量は他 の業種よりも小さい。ただし，ホテルの立地が集中する駅 を含むメッシュ等では，1メッシュあたりの賦存量が 5,000 $\mathrm{kW}$ 以上になる場合があった。同図 (b) の病院の場合，全 メッシュ合計の賦存量はホテルの場合よりも大きく, 同図 (c) の店舗の場合と同程度である。ただし，CGS の単機容 量がホテルよりも大きい施設が多いが，様々な地域に施設 が分布しているため，他の業種と比較して賦存量が小さい メッシュが多い。同図 (c) の店舗の場合, 1 メッシュあたり の賦存量の最大值は 3 業種の中では最も大きく，また，店 舗が存在ずるメッシュ数も多いため, 全メッシュ合計の賦
存量も最も大きい。ただし，大半のメッシュでは，1メッ シュあたりの賦存量は他の業種と同程度である。なお，上 述の住宅用の PV システムや CGS と比較して, 業務部門 3 業種におけるCGS が導入されるメッシュ数は 1 桁少ない ため，賦存量は合計で $210 \mathrm{MW}$ となった。

なお, 本論文では, 温熱需要が小さい事務所などは対象 外とした。しかし，20 kW クラスの小型 CGS においても 排熱を利用した冷熱供給が可能になりつつあり，事務所等 への小型 CGS の導入が拡大する可能性も考えられる。今 後，このような場合を考慮して，業務用 CGS の賦存量を算 定する必要があると考えられる。

\section{5. 考察}

電力需要に対して分散型電源の賦存量が大きいメッシュ では，配電系統への影響も大きくなると考えられる。そこ で, 各メッシュについて, 最大電力需要に対する各分散型 電源の賦存量の比（以下，導入比と呼ぶ）を算定した。結 果を図 13 に示す。同図 (a) は昇順の導入比と累積メッシュ 数との関係，同図 (b) は昇順の導入比と全メッシュにおけ る分散型電源賦存量の累積值との関係を示す。

住宅用 PV システムの場合，同図 (a) に示すように，約 90\%のメッシュにおいて最大電力需要に対する導入比は 


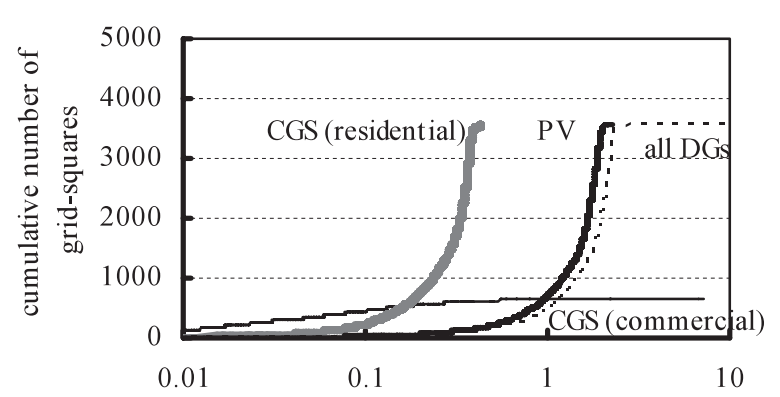

ratio of potential capacity of DGs to maximum electrictity demand in each grid-square

(a) The number of grid-squares

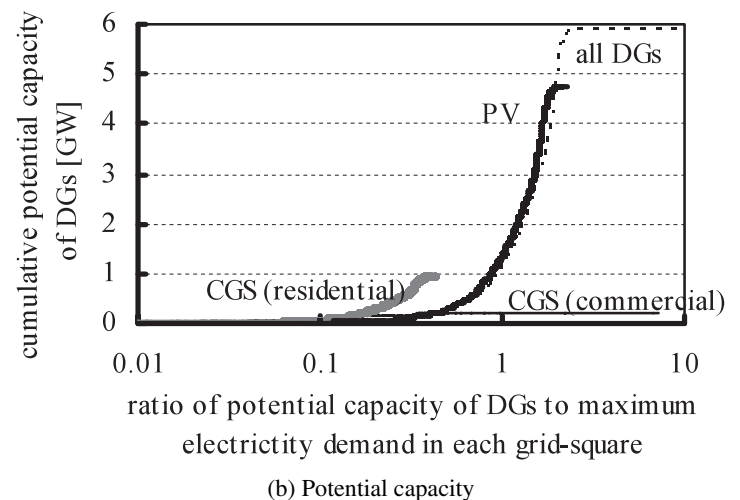

困 13 各メッシュにおける最大電力需要に対す る分散型電源賦存量の比

Fig. 13. Ratio of potential capacity of distributed generators to maximum electricity demand in each grid-square.

200\%以下となった。住宅用 CGS の場合は，同困 (a) に示 すように，ほぼ全てのメッシュにおいて導入比は 40\%以下 となった。さらに，業務用 CGS (3 業種合計) の場合は，導 入比が $10 \%$ 以下のメッシュが $8 \%$ 占めた。また，全ての 分散型電源の合計では, 約 $67 \%$ のメッシュにおいて導入比 は 200\%以下となった。ただし，400\%以上となるメッシュ も数個存在しており，そのような地域への分散型電源の大 量導入に関しては，技術的な対応についての検討が必要に なると考えられる。

このような分散型電源の導入比の統計的な評価は，分散 型電源の大量導入を想定した配電系統をモデル化する際の 一つの目安になると考えられる。例えば，PV システムの導 入容量として最大電力需要の $200 \%$ 想定したモデル系統 を用いた検討において, PV システムの大量導入に電力系統 が対応できることを確認できれば，図 13(a) から PV システ 厶が最大電力需要の $200 \%$ 程度導入される地域数や該当地 域全体の電力需要を見積もることができ,さらに, 図 8(b) から系統側の制約なしに導入可能な PV システムの総量を 統計的に算定できる。

なお，本論文における検討では，メッシュごとの最大電 力需要と分散型電源の賦存量との関係を示したに過ぎない が, 分散型電源の出力が電力系統に与える影響について検 討する際には, 電力需要パターンと各分散型電源の発電パ
ターンとの時間的な関係も考慮する必要ある。そこで筆者 らは，本論文の結果に基づき，日射量の実測データから算 出した PV システムの出力变動特性や CGS の典型的な運 転パターンを考慮し, 地域の電力需要の密度や大きさが異 なる複数の配電系統モデルを用いて, 電圧上昇・変動の観 点から分散型電源の導入可能容量の統計的な算定を試みて いる。その結果については，次報に譲る。

\section{6. あとがき}

本論文では, 様々な地域を対象として分散型電源の賦存量 の統計的に算定するための基礎データとして地域メッシュ 統計に着目し, $1 \mathrm{~km} \times 1 \mathrm{~km}$ の地域単位で民生部門の電力需 要および分散型電源の賦存量を算出した。その結果，例え ばPV システムの場合, 大半のメッシュにおいて賦存量は数 $1,000 \mathrm{~kW} / \mathrm{km}^{2}$ となり, 導入密度は最大でも PV システムの 集中導入の実証地区の数分の一程度となった。また，業務 部門 3 業種（ホテル，病院，店舗）における CGS の賦存量 は, 導入されるメッシュが限られるため, 合計で $210 \mathrm{MW}$ となった。さらに, 地域の最大電力需要に対する分散型電 源の賦存量の比を算定した結果，67\%のメッシュにおいて 導入比は $200 \%$ 以下となった。

本論文で算定した各種分散型電源の賦存量や電力需要に 対する導入比は, 分散型電源の大量導入を考慮した配電系 統モデルを構築する際の一つの目安になると考えられる。 そこで現在, 本論文の結果に基づき, 地域の電力需要の密 度や大きさが異なる複数の配電系統モデルを用いて，系統 運用上の技術的制約からみた分散型電源の導入可能量等に ついて統計的な評価を試みている。なお，上述のように， 本論文の提案手法では, 様々な想定に基づいている。今後, 提案手法による算定結果に基づき様々な検討を行うために は, 典型的な需要地域における実態調査などを反映させて, 評価手法を改善する必要がある。これについては, 今後の 課題としたい。

本論文は, 平成 17 年度文部科学省科学研究費補助金萌芽 研究（No.17656308）の補助を受けた。また，本論文にお ける各種データ収集に協力していただいた卒業生の金由生 君に感謝する。

(平成 18 年 1 月 4 日受付, 平成 18 年 4 月 17 日再受付)

\section{文献}

(1) 電力中央研究所：新エネルギー導入評価分析調査 (II) (1993)

(2) 総務省統計局：地域メッシュ統計平成 12 年度国政調査 (2002)

(3) 総務省統計局：地域メッシュ統計平成 13 年度事業所統計調査 (2003)

（4）総務省統計局：平成 10 年住宅・土地統計調査 確報集計結果（報告 書掲載表) 23 愛知県 第 7 表 (2001)

（5）総務省統計局：平成 13 年事業所企業統計調査全国結果 事業所に関 する集計第 1 表 (2001)

（6）国土庁土地局：「平成 10 年法人建物調査速報集計結果 第 1 巻全国 編 (1998)

（7）柏木孝夫 監修: 天然ガスコージェネレーション計画設計マニュア ル 2000, 日本工業出版 (2000)

（8）日本エネルギー経済研究所計量分析ユニット編：EDMC エネルギー。 
経済統計要覧 (2005 年版),p.83, 財団法人省エネルギーセンター (2005)

（9） 藤井拓郎・下田吉之・森川貴夫・水野 稳：「熱負荷計算を組み込ん だ都市住宅エネルギーエンドユースモデルの開発世帯詳細区分型都 市住宅エンドユースモデルの開発と応用 (1)」, 日本建築学会環境系 論文集, No.589, pp.51-58 (2005)

（10） 総務省統計局：平成 10 年住宅·土地統計調查 確報集計結果（報告 書揭載表) 23 愛知県 第 28 表 (2001)

(11) I. Toda, R. Sakai, S. Nishikawa, and H. Sugihara: "The Evaluation Method on Operation Characteristics of Clustered PV Systems-Influence of the evaluation results by average processing interval-", The Papers of Technical Meeting on Frontier Technology and Engineering, IEE Japan, FTE05-40 (2005) (in Japanese)

戸田一成・境 隆介・西川省吾・杉原裕征：「集中連系型太陽光発 電システムの運転特性の評価法一平均化処理間隔の評価結果への影 響一」, 電気学会新エネルギー・環境研資, FTE05-40 (2005)

（12）電力中央研究所：平成 11 年度 新エネルギー・産業技術総合開発機 構委託業務成果報告書太陽光発電システム実用化技術開発「太陽光 発電システムの実証研究」(高密度連系技術の研究) (2000)

（13） 総務省統計局：平成 10 年住宅·土地統計調查 確報集計結果（報告 書掲載表) 第 35 表 (2001)

（14）井上 隆：「エネルギー消費量と住まい方の実態について」, 日本建 築学会第 2 回住宅エネルギーシンポジウム資料 (2005)

(15) E. Imamura and H. Asano: "Penetration Analysis of Residential PEFC Cogeneration Systems and Heat Pump Systems", Proc. of the 22th Annual Meeting of Japan Society of Energy and Resources, pp.299-302 (2002) (in Japanese)

今村栄一・浅野浩志:「技術間競合を考慮した家庭用 PEFC の普及要因 分析」,第 22 回エネルギー資源学会研究発表会講演論文集, pp.299-302 (2003)

（16）社団法人日本ガス協会: 平成 8 年度都市ガスコージェネレーション 導入実績集 (1997)

(17) 厚生問題研究会：全国病院名鑑 (2002)

（18）オータパブリケイションズ：日本ホテル年鑑P Part1 東日本編，Part2 西日本編 (1992)

(19）デパートニューズ社：百貨店調査年鑑 (1998)

（20） 日本ショッピングセンター協会：ショッピングセンター名鑑 (1994)

(21） 商業界：日本スーパー名鑑店舗編上・下 (1998)
加 藤 丈 佳 (正員) 1996 年 3 月名古屋大学大学院工学研究

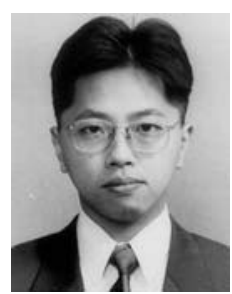
科博士課程後期課程修了。同年 4 月名古屋大学 理工科学総合研究センター助手, 2005 年 5 月同 大学大学院工学研究科助教授, 現在に至る。2002 年国際応用システム分析研究所（IIASA）研究員。 工学博士。エネルギーシステムに関する研究に従 事。エネルギー・資源学会会員。

杉 本 寛 幸

（学生員） 2005 年 3 月名古屋大学大学院工学研

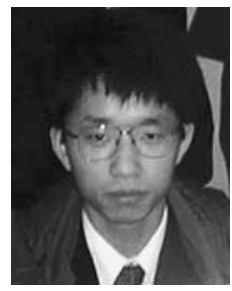
究科博士課程前期課程修了。在学中は配電系統に おける分散型電源の導入影響評価に関する研究に 従事。現在，東京電力株式会社勤務。

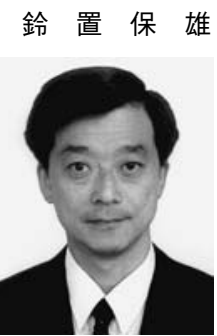

(正員) 1978 年 3 月名古屋大学大学院工学研究 科博士課程後期課程修了。同年 4 月名古屋大学工 学部助手，同講師，同助教授を経て，1995 年 4 月 同大学理工科学総合研究センター教授, 2003 年 4 月同大学大学院工学研究科教授, 現在に至る。 工学博士。主として, 電気電子材料, エネルギー システムに関する研究に従事。IEEE，応用物理学 会，高分子学会，エネルギー・資源学会会員。 